\title{
Analysis of Implementation Effect of Increasing the Export Tax Refund Rate of China's Textiles
}

\author{
*Zhao Hong ${ }^{\mathrm{a}}$, Li Jinjin ${ }^{\mathrm{b}}$
}

Tianjin polytechnic university, Tianjin, China

\begin{abstract}
China's textile exports was deteriorated because of the impact of the global financial crisis. State adopts some support policies in time. This paper mainly analyzes the implementation effect of increasing China's textile and apparel tax refunds to exporters, points out the active and negative effect of those policies to the enterprise export. And emphasizes state and enterprises ought to adopt other measures to pull through the crisis at same time and promote the development of textile industry.
\end{abstract}

Index Terms: Textiles; the export tax refund rate; increasing policy; implementation effect

(C) 2011 Published by MECS Publisher. Selection and/or peer review under responsibility of the International Conference on E-Business System and Education Technology

\section{Introduction}

Textile industry is the traditional industry which helps China to absorb most of the employed population. It has strong ratio of dependence on foreign trade and it is one of the earliest industries which have realized internationalization. Textile industry is an important livelihood industry in quite a long time, and the total textiles consumption of the huge population of 1.3 billion in the domestic market must rely on China's textile industry to meet. Textile industry is a labor-intensive industry and requires mutual cooperation in all aspects of cotton, chemical fiber, dyeing and weaving industries because of its long industrial chain. So textile industry absorbs 20 million labor forces, of which $80 \%$ come from rural areas. The annual output of cotton, wool, hemp and silk can reach more than 9 million tons, and it is related to the livelihood of 100 million farmers. Textile industry is the industry with clear international competitive advantage, and the textile trade owns $1 / 3$ market share in the global market. Textile industry has irreplaceable advantages in the global textile industry, which has a completely industrial chain, strong supporting capacity, clear division of industry and low labor cost.

\footnotetext{
* Corresponding author.

E-mail address: ${ }^{\mathrm{a}}$ zhaohong300160 @126.com, ${ }^{\mathrm{b}}$ jinjin.1520@163.com
} 
State has implemented some support policies in time in order to avoid the negative effect of the global financial crisis, which shows that state attaches importance to the textile industry. In the paper, it will analyze the status of China's textile exports and the implementation effect of increasing the export tax refund rate of China's textiles.

\section{The status of China's textile and apparel exports}

China's textile and apparel exports have increased the position in the world gradually in the last 20 years. China's textile exports in foreign trade play an important role. However, the textile exports have faced enormous challenges because of the changes of world economic and domestic policy environment since 2007.Export growth begins to slow down or even has a declining trend. (see Table I)

TABLE I NATIONAL TOTAL VALUE OF TEXTILE AND APPAREL IMPORT AND EXPORT TRADE(2000-2009)

\begin{tabular}{|c|l|l|c|c|c|c|}
\hline \multirow{2}{*}{ Year } & \multirow{2}{*}{$\begin{array}{l}\text { Import } \\
\text { Export } \\
\text { (bn\$) }\end{array}$} & \multirow{2}{*}{$\begin{array}{l}\text { Export } \\
\text { (bn\$) }\end{array}$} & Import & \multicolumn{3}{|c|}{ Year On Year Cumulative } \\
\cline { 5 - 8 } & & $\begin{array}{c}\text { Import } \\
\text { and } \\
\text { export }\end{array}$ & Export & Import \\
\hline 2000 & 66.934 & 53.044 & 13.890 & 19.84 & 21.20 & 14.89 \\
\hline 2001 & 68.048 & 54.323 & 13.725 & 1.66 & 2.41 & -1.99 \\
\hline 2002 & 77.387 & 63.018 & 14.369 & 13.72 & 16.01 & 4.69 \\
\hline 2003 & 96.070 & 80.484 & 15.586 & 24.15 & 27.72 & 8.47 \\
\hline 2004 & 114.189 & 97.385 & 16.804 & 18.86 & 21.02 & 7.81 \\
\hline 2005 & 134.634 & 117.535 & 17.099 & 17.90 & 20.69 & 1.76 \\
\hline 2006 & 165.136 & 147.085 & 18.051 & 22.66 & 25.14 & 5.57 \\
\hline 2007 & 194.353 & 175.616 & 18.737 & 17.43 & 19.11 & 3.69 \\
\hline 2008 & 208.270 & 189.624 & 18.646 & 7.16 & 7.98 & -0.49 \\
\hline 2009 & 188.256 & 171.332 & 16.924 & -9.61 & -9.65 & -9.24 \\
\hline
\end{tabular}

Source: China Customs, China Textile Industry Association Statistics Center

From the penultimate column of the above table, we can see that the cumulative percentage of China's textile and apparel exports from $25.14 \%$ in 2006 fell to $19.11 \%$ in 2007 .It further dropped to $7.98 \%$ significantly in 2008, and in 2009 it was $-9.65 \%$. Faced with such a situation, state adopted a policy to raise export tax refund.

*This work was supported by Program for New Century Excellent Talents in University (NCET).

*corresponding author.: Zhao Hong,, Tel: 86-22-24528371, fax: 86-22-24528000, Email: zhaohong300160@126.com 


\section{Textile and Apparel export tax refund}

\section{A. The Process of China's Textile and Apparel Export Tax Refund}

From the history of export tax refund adjustment, China's export tax refund went through four stages: decline - increase-decline - increase.

The first stage: Textile and apparel export tax refund rate was $13 \%$ in January 1994, then it gradually reduced from $13 \%$ to $6 \%$ in December 1996 at twice.

The second stage: From January 1998 to July 2001, textile and apparel export tax refund rate was gradually transformed from 6\% to $15 \%$ three times. The reason of increasing the export tax refund is to get rid of the 1998 Asian financial crisis on the tremendous impact of China's exports.

The third stage: From January 2004 to July 2007, textile and apparel export tax refund rate gradually reduced from $15 \%$ to $11 \%$ at twice.

The fourth stage: From August 2008 to April 2009, part of the textile and apparel export tax refund rate was gradually transformed from $11 \%$ to $16 \%$ in four separate times.

We focus on analyzing the fourth stage. In order to reduce the operating pressure faced by the textile industry, from August 2008 to April 2009, State increased textile and apparel export tax refund rate four times. Textile and apparel export tax refund rate increased from $11 \%$ to $16 \%$ in four separate times. The process is as follows: Ministry of Finance, State Administration of Taxation jointly issued a notice in July 30th, 2008: since August 1st, 2008, part of the textile and apparel export tax refund rate increased from $11 \%$ to $13 \%$. They jointly issued the notice in October 21st that they will raise textile and apparel export tax refund rate to $14 \%$ again starting from November 1st. At the very beginning of February, export tax refund rate of the textiles and apparel was increased from $14 \%$ to $15 \%$.In less than two months; state raised the textile and apparel export tax refund rate to $16 \%$ again.

\section{B. Implementation Results of the Export Tax Refund}

Since the implementation of export tax refund policy, it has provided policy space for enterprises responding to the plight of the export. The specific effect is as follows:

(1) Reducing export costs and increasing profit margins of textile and apparel enterprises. Increasing export tax refund rate for textile export enterprises is definitely beneficial. Under the premise of the sale price of the commodity without changing, if the tax rate increases $1 \%$, it means that the business gross profit margin will increase $1 \%$. In the short term, measured by the static price-earnings ratio, without consideration of the partial interest which was probably shared by importers, increasing the export tax refund rate will directly increase enterprises' profits. Calculated by the level of exports increase by $15 \%$, industry sales increase by $15 \%$, gross profit increase by $12 \%$ in 2008, if textile and apparel export tax refund rate increases 2 percentage points, it will directly increase the textile and apparel enterprises profit of US $\$ 2.7$ billion. Calculated by the exchange rate 6.8 , the industry will increase profits of RMB 18.4 billion. If the profits of increasing export tax refund industry profits accounted for $14 \%$ of the total industry profits, the profitability of the textile and apparel enterprises will increase by 0.6 percentage points approximately.

For textile and apparel export enterprises, the benefit of increasing export tax refund rate is positive and immediate (see Table II), and in short-term it will help textile and apparel SMEs relieve the loss-making situation.

TABLE II INFLUENCE OF EXPORT TAX REFUND POLICY ON THE PROFIT ABILITY OF TEXTILE INDUSTRY IN 2009

\begin{tabular}{|l|c|c|c|c|}
\hline Time: & Export & General Trade & The & Affected \\
Month & Tax & Exports & Increasing & Number \\
& Refund & (bn \$) & Number Of & (bn RMB) \\
& Rate(\%) & & $\begin{array}{c}\text { Points Over } \\
\text { The Same }\end{array}$ & \\
& & & $\begin{array}{c}\text { Period(percen } \\
\text { tage point) }\end{array}$ & \\
& & & & \\
\hline
\end{tabular}




\begin{tabular}{|c|c|c|c|c|}
\hline 1 & 14 & 11.6 & 3 & 2.382 \\
\hline 2 & 15 & 4.4 & 4 & 1.217 \\
\hline 3 & 15 & 8.8 & 4 & 2.421 \\
\hline 4 & 16 & 9.3 & 5 & 3.197 \\
\hline 5 & 16 & 9.3 & 5 & 3.162 \\
\hline 6 & 16 & 10.4 & 3 & 2.142 \\
\hline 7 & 16 & 12.2 & 3 & 2.509 \\
\hline 8 & 16 & 11.8 & 3 & 2.420 \\
\hline 9 & 16 & 12.4 & 2 & 1.690 \\
\hline 10 & 16 & 11.0 & 2 & 1.509 \\
\hline 11 & 16 & 10.4 & 2 & 1.416 \\
\hline total & - & 111.6 & - & 24.1 \\
\hline
\end{tabular}

Source: Statistics Center of China Textile Industry Association

(2) It provides a buffer for the minor textile and apparel enterprises to restructure and adjust and for the local industry to upgrade. Since 2008, the textile and apparel industry has tended to focus on the preponderant enterprises, but for SMEs the living environment was deteriorated gradually. A large number of SMEs face bankruptcy and the threat of closure. The local government which takes the textile and apparel industry as the pillar also faced a huge pressure.

The total profits of chemical industry increased by $187.4 \%$ year on year from January 2009 to November 2009. Viscose industry increases export tax refund rate from 5\% to $16 \%$. Viscose industry increases the export tax refund rate 11 percentage points and the situation of exports decline has been reversed since May 2009. The increasing degree of products increases monthly. January to November, the industry profit increased by 6.6 times on year-on-year basis. The increase of export tax refund rate in terms of improving corporate profitability has significant effect and a group of desperate enterprises back to life.

\section{Analysis}

The above is the achievement that this policy has been achieved since it was carried out. Then we will get further verification through data.

We use total exports of China's textile industry $(Y)$, output value $\left(X_{1}\right)$, the exchange rate during this period $\left(X_{2}\right)$, the U.S. GDP $\left({ }^{X_{3}}\right)$, foreign direct investment $\left(X_{4}\right)$, and export tax refund rate $\left({ }^{X_{9}}\right)$ in 1994-2009 as statistical data, using SPSS15 .0 statistical software to make regression and estimate the model parameters values of the textile industry.

TABLE III TOTAL TEXTILE EXPORTS AND THE VARIOUS FACTORS IN 1994-2009

\begin{tabular}{|c|c|c|c|c|c|c|}
\hline Year & $\begin{array}{c}\text { Total } \\
\text { Exports( } \\
\text { bn\$) }\end{array}$ & $\begin{array}{c}\text { Output } \\
\text { Value(bn } \\
\text { RMB) }\end{array}$ & $\begin{array}{c}\text { Export } \\
\text { Tax } \\
\text { Refund } \\
\text { Rate }\end{array}$ & $\begin{array}{c}\text { The } \\
\text { Exchang } \\
\text { e Rate }\end{array}$ & $\begin{array}{c}\text { U.S. } \\
\text { GDP } \\
\text { (bn\$) }\end{array}$ & $\begin{array}{c}\text { FDI } \\
\text { (bn\$) }\end{array}$ \\
\hline 1994 & 24.575 & 494.933 & 0.13 & 8.45 & 708.52 & 33.770 \\
\hline 1995 & 35.000 & 460.400 & 0.10 & 8.32 & 741.47 & 37.520 \\
\hline 1996 & 30.938 & 472.229 & 0.06 & 8.30 & 783.85 & 41.730 \\
\hline 1997 & 45.577 & 476.028 & 0.06 & 8.28 & 833.24 & 45.260 \\
\hline 1998 & 40.500 & 437.627 & 0.11 & 8.28 & 879.35 & 45.460 \\
\hline 1999 & 40.300 & 452.982 & 0.15 & 8.28 & 935.35 & 40.398 \\
\hline 2000 & 48.500 & 514.930 & 0.15 & 8.28 & 995.15 & 40.772 \\
\hline
\end{tabular}




\begin{tabular}{|l|l|l|l|l|l|l|}
2001 & 51.900 & 562.156 & 0.15 & 8.28 & 1028.62 & 46.880 \\
\hline 2002 & 62.200 & 637.079 & 0.15 & 8.28 & 1064.23 & 52.740 \\
\hline 2003 & 79.300 & 772.520 & 0.17 & 8.28 & 1114.21 & 53.505 \\
\hline 2004 & 95.100 & 1443.810 & 0.13 & 8.28 & 1186.78 & 60.630 \\
\hline 2005 & 115.030 & 1267.165 & 0.13 & 8.07 & 1263.84 & 53.127 \\
\hline 2006 & 144.000 & 1529.346 & 0.13 & 7.81 & 1339.89 & 65.821 \\
\hline 2007 & 167.937 & 1847.336 & 0.11 & 7.30 & 1407.76 & 74.768 \\
\hline 2008 & 185.220 & 2114.593 & 0.13 & 6.83 & 1444.14 & 92.395 \\
\hline 2009 & 167.000 & 3426.804 & 0.16 & 6.84 & 1419.04 & 90.033 \\
\hline
\end{tabular}

Source: Textile exports, output vaule data from the Statistics Center of China Textile Industry Association; textile export tax refund rate, foreign direct investment data from the Chinese Ministry of Commerce; exchange rate data from the National Bureau of Statistics; U.S. GDP data from the U.S. Economic Analysis Bureau.

The following is the results of multiple regression analysis from the software SPSS15.0: Table IV,V,VI,VII respectively represent the correlation coefficient table, the model summary, the coefficient table and the models of the variable.

From the correlation coefficient table, we can know the Pearson correlation coefficient and significant test of one-tailed probability called $\mathrm{p}$ value. And the export value of textiles, the output value, the exchange rate, the GDP in America and the correlation coefficients of foreign direct investment are 0.894, $-0.905,0.959$, and 0.953 respectively. However, the correlation coefficient of the rate of export tax refund is only 0.251.

We can see from TABLE $\mathrm{V}$ that with the increasing of explanatory variables, the goodness of fit of the equation is on the rise. The multiple correlation coefficient of Model 3 which has U.S. GDP, exchange rate and textile export tax rebate rate these three variables is 0.989.Its coefficient of determination is 0.978 and its adjusted coefficient of determination is 0.973 . So the final model is the third model.

The TABLE VI is a list of multiple linear regression coefficients, and it shows the partial regression coefficients, standard errors, constant, standardized partial regression coefficient, $t$ statistic observations of regression coefficient test and the corresponding probability called $p$ value of all models. At the case of a given level of significance 0.10 , the variables in model 3 are statistically significant.

The final table shows the relevant statistics of model variables outside of the regression equation. The two variables (output value and foreign direct investment) outside the model 3 equation, their probability of $p$ value are 0.598 and 0.943 respectively, and greater than 0.10 , so it can not be introduced the equation.

TABLE IV

THE CORRELATION COEFFICIENT TABLE

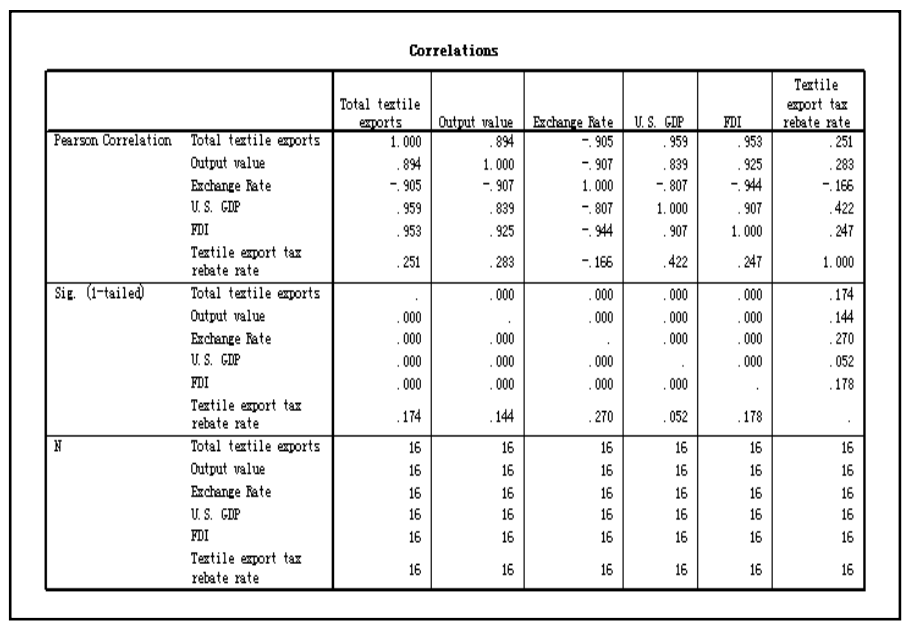




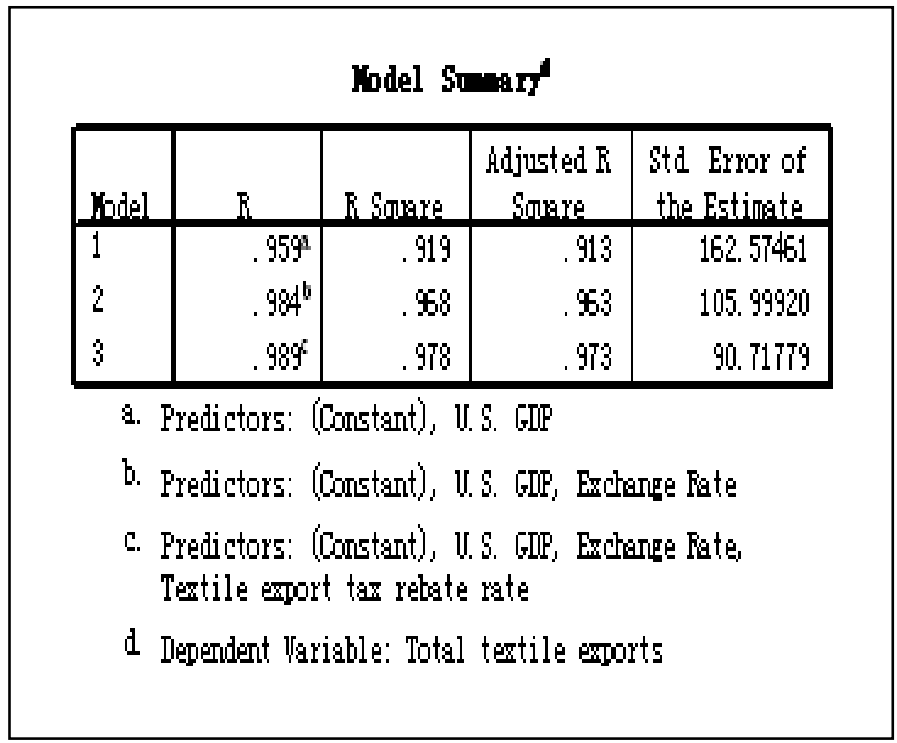

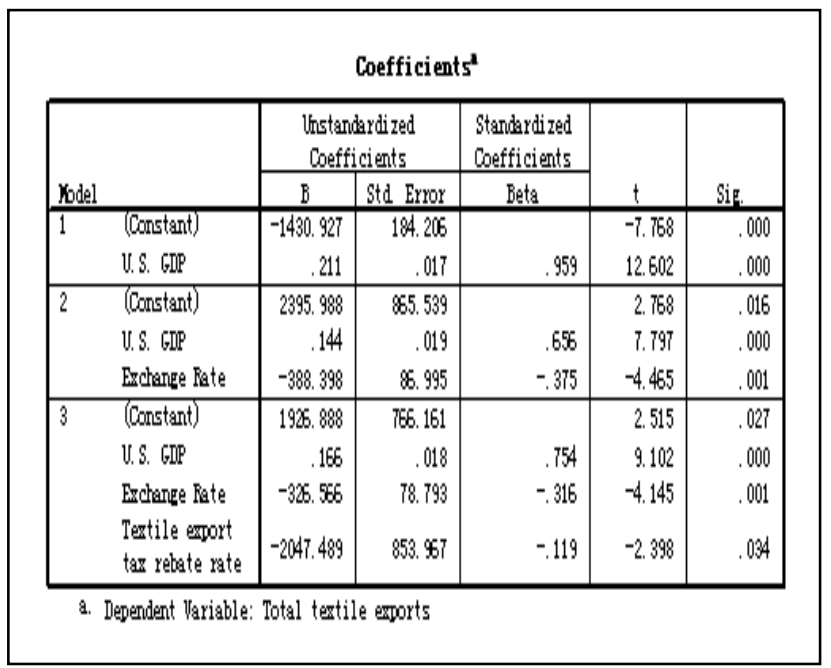


TABLE VII THE MODELS OF THE VARIABLE

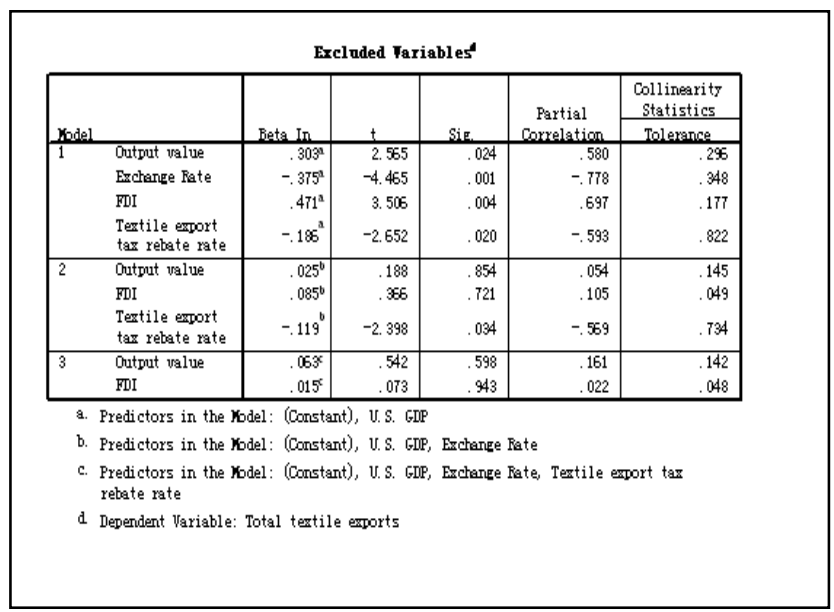

In sum, the multiple linear regression equation based on the model 3 is:

$$
\mathrm{Y}=1926.88-326.566 \mathrm{X}_{2}+0.166 \mathrm{X}_{3}-2047.489 \mathrm{X}_{5}
$$

\section{Conclusion}

As can be seen from the above, the adjustment of export tax refund rate works for export enterprises to a certain extent. But in the long run, it is unfavorable to change the economic growth mode of enterprises, improve the domestic environment and facilities and upgrade the industrial structure. If export enterprises want to achieve sustained and stable development, they can not depend on government policy. They should start from their own transformation, change the traditional development model, improve management ability, and strengthen R \& D and marketing management.

In short, the current U.S. subprime mortgage crisis in the global economic downturn caused by the context weakens the demand in the international market. Increasing export tax refund rate on exports will be limited to promote the exports and state should also adopt other measures to help domestic enterprises to pull through the crisis. Meanwhile, China's enterprises should actively develop "internal strength." Only by raising the technological content of products, improving product quality, developing new products with high added value, optimizing industrial structure, improving management, promoting the upgrading of production equipment, building their own brands and extending the industrial chain can the enterprises be truly out of the crisis and achieve sustainable development.

\section{References}

[1] Gu Yongfen,Wu Qian and Chen Wenzong, "Empirical analysis of export tax refund policy on China's textile industry' structure adjustment" Economic issues, 2008,(08).

[2] Guo Mingxi and Xiao Ning, "The influence of increasing export tax refund rate on textile export trade" Forest Education, 2009,(06).

[3] Dai Jinzhang and Wang Ying, "Analysis of evolution of China's textile export tax refund policy and its effect” Monthly price, 2009, (10).

[4] Wei Rundi, "Empirical analysis of influence on regulating China's export tax refund rate on textile exports"Modernization, 2009, (06). 